\title{
Effects of Plant Tissue and DNA Purification Method on Randomly Amplified Polymorphic DNA-based Genetic Fingerprinting Analysis in Carrot
}

\author{
L.S. Boiteux ${ }^{1}$ \\ Plant Breeding and Plant Genetics Program, 1575 Linden Drive, University of Wisconsin-Madison, \\ Madison, WI 53706, and EMBRAPA-Centro Nacional de Pesquisa de Hortaliças (CNPH), C.P. 218, \\ 70359-970, Brasilia-DF, Brazil
}

\author{
M.E.N. Fonseca ${ }^{1}$ \\ Plant Breeding and Plant Genetics Program, 1575 Linden Drive, University of Wisconsin-Madison, \\ Madison, WI 53706, and EMBRAPA-Centro Nacional de Pesquisa de Recursos Geneticos e \\ Biotecnologia (CENARGEN), C.P. 02372, 70849-970, Brasilia-DF, Brazil \\ P.W. Simon ${ }^{2}$ \\ U.S. Department of Agriculture, Agricultural Research Service, Vegetable Crops Research Unit, \\ Department of Horticulture, 1575 Linden Drive, University of Wisconsin-Madison, Madison, WI 53706
}

\begin{abstract}
AdDITIONAL INDEX wORDS. marker-assisted selection, polymerase chain reaction, PCR, RAPD
ABSTRACT. Seven plant genomic DNA purification protocols were evaluated for genetic fingerprinting analysis using six tissues obtained from inbred carrot (Daucus carota L.) lines. Evaluations included 1) DNA yield, 2) DNA purity, 3) DNA cleavage with HindIII, 4) DNA integrity, and 5) DNA suitability for amplification in a random amplified polymorphic DNA (RAPD) system. Significant differences were observed among tissues and purification methods for the total amount of DNA. An extraction method using CTAB buffer + organic solvents gave the best results in DNA yield, purity, and HindIII cleavage when compared with the other six nonorganic extraction methods. Of the tissues examined, flowers yielded the most DNA (average

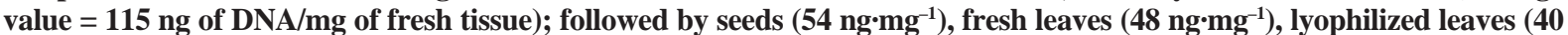
$\left.\mathrm{ng} \cdot \mathrm{mg}^{-1}\right)$, calli $\left(22 \mathrm{ng} \cdot \mathrm{mg}^{-1}\right)$, and tap roots $\left(4 \mathrm{ng}^{\circ} \mathrm{mg}^{-1}\right)$. For most of the preparations, the DNA showed no traces of degradation. However, DNA preparations were not consistently accessible to HindIII cleavage in all tissue-extraction method combinations. Uncut DNA was observed chiefly in extractions from flowers and fresh leaves suggesting a tissue-specific adverse effect on restriction endonuclease activity. Differences in RAPD band (amplicon) intensity and number were observed across tissues and DNA extraction methods using identical PCR conditions for RAPD. Callus was the best type of tissue for RAPD-based fingerprinting yielding a consistently higher number of more intense amplicons when compared to the other tissues. In flowers and seeds, only DNA obtained with the CTAB extraction method could be amplified. Polymorphisms deviating from genetic expectations were mainly observed in root and fresh leaf DNA, indicating that some RAPD markers may not present satisfactory levels of reproducibility. Judicious and uniform selection of DNA purification method as well as tissue source for DNA extraction are, therefore, important considerations for reliable RAPD-based DNA fingerprinting analysis in carrot. In addition, our studies allowed the identification of a better combination of procedures for use in routine manipulations of carrot DNA such as RFLP-RAPD-based cultivar fingerprinting, molecular mapping, screening of transgenic plants, construction of genomic libraries, and gene cloning.
\end{abstract}

The purification of high molecular weight DNA from plant tissues is essential for many procedures used in molecular genetics and in applied plant breeding. The large number of samples often required in breeding programs demands purification methods that provide high quality DNA, rapidly, simply, and inexpensively (Weising et al., 1995). Although DNA yield is a significant factor for fingerprinting and linkage mapping studies, it has been less important with the advent of polymerase chain reaction (PCR)-based methods, which often circumvent requirements for relatively large quantities of genomic DNA (Rogers and Bendich, 1994). Random amplified polymorphic DNA (RAPD) analysis (Williams et al., 1990) is one of the most versatile and powerfulPCR-based tools for plant genetic and

Received for publication 25 Mar. 1998. Accepted for publication 24 Aug. 1998 Use of trade name does not imply endorsement of products named nor criticism of similar ones not named. We thank J. Staub and T.C. Osborn for the critical review of the manuscript. The cost of publishing this paper was defrayed in part by the payment of page charges. Under postal regulations, this paper therefore must be hereby marked advertisement solely to indicate this fact.

${ }^{1}$ Graduate student.

${ }^{2}$ Research geneticist and professor; to whom reprint requests should be addressed. evolutionary studies but its reproducibility does rely on a high quality DNA template (Weising et al., 1995).

Extraction of highly purified genomic DNA from plant tissues is a difficult task due in part to their rigid cell wall composed of large amounts of complex carbohydrates (Hattori et al., 1987). Contamination by polysaccharides has been reported as the most common problem affecting plant DNA purity (Demeke and Adams, 1992; Murray and Thompson, 1980). Some classes of polysaccharides reduce the activity of polymerases, ligases, and restriction endonucleases (Do and Adams, 1991; Fang et al., 1992; Furokawa and Bhavadna, 1983; Shioda and Marakami-Muofushi, 1987). PCR is based on the efficient action of a thermostable polymerase such as Thermus aquaticus (Taq) DNA polymerase (Arnheim and Erlich, 1992). Several factors present in plant DNA preparations, which inhibit Taq polymerase activity have been already reported (Gelfand and White, 1990). Therefore, false negative polymorphic bands have been observed in PCR-based fingerprinting as a result of contamination by polysaccharides and/or other DNA-binding substances, which may confound the interpretation of genetic differences between individual samples (Gelfand and White, 1990). 
Comparative studies evaluating efficiency of distinct DNA purification methods for use in molecular genetic analysis in carrot (Daucus carota) have not been reported. However, negative consequences of unsuitable DNA purification protocols have been described in plants. The major adverse effects are 1) relatively low DNA yields; 2) coisolation of DNA-severing quinonic compounds (brown pigments) associated with the activity of polyphenol oxidases; 3) low DNA utility due to contaminants (polyphenols and other secondary compounds) which affect restriction endonuclease, polymerase and/or ligase activity, and 4) premature DNA degradation (Rogers and Bendich, 1994). Purification of high quality carrot DNA for molecular studies has been reported using CsCl gradients (Vivek and Simon, 1998). However, this protocol is time-consuming and cannot be applied in large scale experiments. Encouraging results with RAPD-based mapping in carrot have been reported using DNA isolation with organic solvents (Schulz et al., 1994). However, inhibition of PCR by traces of organic solvents (Gelfand and White, 1990) as well as their toxicity (Chaves et al., 1995) are drawbacks to this approach.

In this work, seven DNA purification methods (a standard protocol with organic solvents and six purification methods without organic solvents) were evaluated. In addition, we examined the relative yield and purity of these DNA preparations obtained from six plant tissues commonly used as source for nucleic acid extraction in carrot breeding. We investigated the effects of several combinations of DNA purification methods per tissue on the number and intensity of RAPD bands (amplicons). These studies also allowed the identification of the best procedures for use in routine manipulations of genomic carrot DNA.

\section{Materials and Methods}

Plant material. Fresh and lyophilized leaves obtained from 35-d-old greenhouse-grown plants, tap roots, mature whole seed, inflorescence, and callus were used as DNA sources. Tap roots (25 to $75 \mathrm{~g}$ ) were stored at $4{ }^{\circ} \mathrm{C}$ before sampling. Calli were collected one month following subculture (incubated in the dark at $25^{\circ} \mathrm{C}$ ) on a modified Murashige and Skoog (1962) solid medium supplemented with 2,4D (1 ppm) and kinetin (0.02 ppm). Young inflorescence (whole umbellets) were obtained before pollen formation (2 to $7 \mathrm{~cm}$ in diameter) from field-grown plants. All tissues were taken from the line 'B 9304' (Simon et al., 1990) except for calli that were obtained from the line 'B 493' (Simon et al., 1990). These highly inbred carrot lines were selected for this study to reduce plant-to-plant variation. All samples consisted of $1 \mathrm{~g}$ of fresh tissue. Lyophilization of one gram of fresh leaf tissue used in this assay resulted in $\approx 0.14 \mathrm{~g}$ of lyophilized tissue.

Procedures common to AlL Methods. All samples were ground in liquid nitrogen $\left(\mathrm{LN}_{2}\right)$ using a mortar and pestle. The $\mathrm{LN}_{2}$ procedure was used because it had been previously found to produce DNA yields of higher average molecular weight when compared to direct grinding of fresh tissue in buffer (Doyle and Doyle, 1990). Lyophilized leaves were also processed using $\mathrm{LN}_{2}$. Pellets from the final purification step were air-dried at $37^{\circ} \mathrm{C}$ for 10 to $15 \mathrm{~min}$ and resuspended in $500 \mu \mathrm{L}$ of TE buffer $(10 \mathrm{~mm}$ Tris pH 8.0, 1 mm EDTA) at $4{ }^{\circ} \mathrm{C}$ overnight. Samples were stored in microcentrifuge tubes at $-20^{\circ} \mathrm{C}$ until analysis. RNase treatment (to remove coisolated RNAs) was not performed. Three replications (i.e., three different 1-g samples of the same tissue in three individual DNA extractions) for each extraction method-tissue combination were taken for analysis. Data on the DNA yield were subjected to analysis of variance (ANOVA) using SAS/STAT guide for personal computers (version 6, SAS Institute, Cary,
N.C.). Differences among means were tested using the Fisher's least square difference (LSD) method.

DNA EXTRACTION METHODS. Seven methods for extraction of genomic DNA from carrot tissues were compared. Method 1 was a standard CTAB (cetyltrimethylammonium bromide) buffer and organic solvents (Doyle and Doyle, 1990; Rogers and Bendich, 1994; Saghai-Maroof et al., 1984), but with minor modifications. Pulverized samples were dispersed in $10 \mathrm{~mL}$ of extraction buffer $[500 \mathrm{~mm}$ Tris $\mathrm{pH} 8.0,1.4 \mathrm{MNaCl}, 2 \%(\mathrm{w} / \mathrm{v}) \mathrm{CTAB}, 0.2 \%$ beta-mercaptoethanol, 20 mm ethylenediamine tetraacetic acid (EDTA)] and incubated at 65 ${ }^{\circ} \mathrm{C}$ for 60 min with occasional mixing by gentle tube inversion. Ten milliliters of 24 chloroform : 1 isoamyl alcohol (v/v) was added (Rogers and Bendich, 1994), and the solution was mixed by inversion to form an emulsion that was centrifuged at 11,240 $g_{\mathrm{n}}$ for $10 \mathrm{~min}$ at $4{ }^{\circ} \mathrm{C}$. The aqueous phase was removed, and $2 / 3$ volume of ice-cooled isopropanol was added and mixed by gentle inversion. Solutions were centrifuged at 11,240 $g_{\mathrm{n}}$ for $10 \mathrm{~min}$. The pellet was rinsed with $2 \mathrm{~mL}$ of $76 \%$ ethanol $+10 \mathrm{~mm}$ ammonium acetate, allowed to air-dry for up to $15 \mathrm{~min}$ and then resuspended in TE buffer. Method 2 was that described by Edwards et al. (1991). Samples were dispersed into $10 \mathrm{~mL}$ of the extraction buffer [200 mm Tris pH 7.5, $250 \mathrm{~mm} \mathrm{NaCl}$, $25 \mathrm{~mm}$ EDTA, $0.5 \%$ (w/v) sodium dodecyl sulfate (SDS)] vortexed briefly, and centrifuged at $13,191 g_{\mathrm{n}}$ for $1 \mathrm{~min}$ at room temperature. The aqueous phase was removed, and then 1 volume of isopropanol (at room temperature) was added and mixed by gently inversion. After $5 \mathrm{~min}$ (at room temperature) the solution was centrifuged at $13,191 g_{\mathrm{n}}$ for $5 \mathrm{~min}$ and the pellet was air-dried and resuspended in TE buffer. Method 3 was a modification of Edwards et al. (1991) using an extraction solution [1 $\mathrm{m}$ Tris pH 8.0, $250 \mathrm{~mm} \mathrm{NaCl}, 25 \mathrm{~mm}$ EDTA, $0.5 \%$ (w/v) SDS, $10 \mathrm{~mm}$ beta-mercaptoethanol] differing in buffering power (Wang et al., 1993; Steenkamp et al., 1994) from the original method 2. After the second centrifugation at 13,191 $g_{\mathrm{n}}$, the pellet was air-dried for up to $15 \mathrm{~min}$. TE buffer $(1 \mathrm{~mL})$ was added, the pellet was dissolved and the high-salt wash was used as described by Fang et al. (1992). The final concentration of $\mathrm{NaCl}$ was adjusted to $1 \mathrm{M}(250 \mu \mathrm{L}$ from a stock solution of $5 \mathrm{M})$, and then 2 volumes $(2 \mathrm{~mL})$ of ethanol were added. After $10 \mathrm{~min}$ (at room temperature) the solution was centrifuged at $11,240 g_{\mathrm{n}}$ for $15 \mathrm{~min}$. The pellet was washed with cold $75 \%$ ethanol solution, air-dried, and resuspended in TE buffer. Method 4 used a protocol similar to that described in details by Dellaporta et al. (1983) but with a minor modification [0.1\% (w/v) SDS was added to the extraction buffer]. Method 5 consisted of a combination of two plant genomic DNA purification methodologies (Dellaporta et al., 1983; Do and Adams, 1991) with an extraction solution with high buffer capacity and alkaline $\mathrm{pH}$ (Steenkamp et al., 1994; Wang et al., 1993). Samples were dispersed in $10 \mathrm{~mL}$ of extraction buffer (identical to that described in method 3 ) preheated to $65^{\circ} \mathrm{C}$. Solution was mixed by several tube inversions, and incubated for 10 to $15 \mathrm{~min}$ at $65{ }^{\circ} \mathrm{C}$. The solution was then allowed to cool at room temperature and the extract was emulsified in $1 / 3$ volume $(3.3 \mathrm{~mL})$ of potassium acetate $5 \mathrm{~m}$ by gentle inversion and incubated $0^{\circ} \mathrm{C}$ (on ice) for $20 \mathrm{~min}$. After centrifugation (25,289 $g_{\mathrm{n}}$ for $20 \mathrm{~min}$ at $4^{\circ} \mathrm{C}$ ), the aqueous phase was removed, and 1 volume of isopropanol (at room temperature) was added and mixed by gentle inversion. After 2 to $5 \mathrm{~min}$ the solution was centrifuged at 13,191 $g_{\mathrm{n}}$ for $10 \mathrm{~min}$, and the resulting pellet was treated essentially as described in method 2. Method 6 was a modification of method 5, which includes, after isopropanol precipitation, the same polysaccharide-removing high-salt precipitation treatment described in method 3. In method 7 (G. Yerk-Davis, personal communication), the samples were dispersed into $4 \mathrm{~mL}$ of a preheated $\left(65^{\circ} \mathrm{C}\right)$ extraction buffer (100 mm Tris pH 8.2, $350 \mathrm{~mm}$ Sorbitol, $5 \mathrm{~mm}$ EDTA) + $4 \mathrm{~mL}$ of a lysis buffer [200 mм Tris pH 7.5, 5 mм EDTA, $2000 \mathrm{~mm} \mathrm{NaCl}$, 
Table 1. Analysis of variance (ANOVA) for the genomic DNA yield obtained by using seven extraction methods in combination with six distinct tissues of carrot (Daucus carota).

\begin{tabular}{lrrc}
\hline \hline $\begin{array}{l}\text { Source of } \\
\text { variation }\end{array}$ & df & MS & F value \\
\hline Methods & 6 & 2629.60 & $10.42^{*}$ \\
Plant tissue & 5 & 30283.81 & $120.03^{*}$ \\
Method $\times$ tissue & 30 & 171.47 & $0.68^{\text {Ns }}$ \\
Error & 84 & 252.38 & --- \\
\hline Ns** Non
\end{tabular}

Ns, ${ }^{*}$ Nonsignificant and significant at $P=0.01$, respectively.

$1 \%(\mathrm{w} / \mathrm{v}) \mathrm{CTAB}]+0.8 \mathrm{~mL}$ of $20 \%$ Sarcosyl. Solution was vortexed and incubated by $45 \mathrm{~min}$ (at $65^{\circ} \mathrm{C}$ ) with occasional mixing by tube inversion. After incubation, the solution was allowed to cool at room temperature, and ammonium acetate $10 \mathrm{~m}$ (1/2 volume) was added and the solution was then vortexed briefly. After centrifugation $\left(13,191 g_{\mathrm{n}}\right.$ for $\left.5 \mathrm{~min}\right)$ the aqueous phase was removed and 2 volumes of ice cold isopropanol were added and mixed gently. The pellet obtained after centrifugation $\left(13,191 g_{\mathrm{n}}\right.$ for $\left.1 \mathrm{~min}\right)$ was then air-dried and resuspended in TE buffer.

FLUOROMETRY, SPECTROPHOTOMETRY, AND AGAROSE GEL ELECTROPHORESIS. DNA concentrations were determined with a TKO 100 Mini Fluorometer (Hoefer Scientific Instruments, San Francisco, Calif.) using bis-benzimidazole dye (Hoechst 33258). Values were transformed to $\mu \mathrm{g} \cdot \mathrm{g}^{-1}$ of DNA on a fresh tissue basis. The purity of genomic carrot DNA was evaluated by measuring absorbance data $\left(\mathrm{A}_{260 \mathrm{~nm}} / \mathrm{A}_{280 \mathrm{~nm}}\right.$ ratio) with a spectrophotometer (model UV 160U; Shimadzu Scientific Instruments Inc., Md.). The size, purity, and integrity of DNA were determined by agarose gel electrophoresis using $\lambda$ phage DNA cleaved with HindIII (Promega, Madison, Wis.) as a size standard. Electrophoresis was done in a horizontal gel system (model H4; Bethesda Research Laboratories, Gaithersburg, Md.) in $0.8 \%$ agarose in TAE buffer $(40 \mathrm{~mm}$ Tris-acetate $\mathrm{pH} 7.6,1 \mathrm{~mm}$ EDTA) at constant voltage of $60 \mathrm{~V}$ for 3 to $6 \mathrm{~h}$. Samples of solubilized DNA $(1 \mu \mathrm{g})$ were heated for $10 \mathrm{~min}$ at $65^{\circ} \mathrm{C}$ and mixed with $20 \mu \mathrm{L}$ of loading buffer $[0.25 \%$ bromophenol blue and xylene cyanol, $40 \%$ (w/v) sucrose] before loading on the gel. Two gels per replication were used to evaluate genomic DNA integrity.

RESTRICTION ENDONUCLEASE DIGESTION AND SPERMIDINE TREATMENT. All DNA preparations were digested individually with HindIII (Promega) using three units of enzyme per microgram of DNA in a $240 \mu \mathrm{L}$ reaction. Reactions were incubated at $37^{\circ} \mathrm{C}$ for at least $5 \mathrm{~h}$. HindIII was chosen as a diagnostic enzyme because of its sensitivity to polysaccharide contaminants (Demeke and Adams, 1992). Each sample was subjected to electrophoresis on $0.8 \%$ agarose gel as described above and visualized by staining the gel with ethidium bromide (Sambrook et al., 1989). In an attempt to improve DNA digestion, in some samples, the final DNA preparations from tissues with incomplete or partial digestion after HindIII treatment were also treated with spermidine [ $N$-(3-aminopropyl)-1-4 butanediamine] obtained from Sigma Chemical Co. (St. Louis, Mo.) This treatment was performed by adding $5.0 \mu \mathrm{L}$ of $0.1 \mathrm{M}$ spermidine to the entire DNA preparation before digestion with HindIII (Dellaporta et al., 1983). Samples were allowed to be digested by HindIII and subjected to electrophoresis in identical conditions as described above. Predigesting DNA template with restriction endonucleases has been employed as a new tool to improve the detection of polymorphisms in RAPD analysis while reducing nonspecific amplification (Koebner, 1995; Riede et al., 1994).

Polymerase Chain ReACTION AND RAPD ANALYSIS. DNA amplification was performed by adding $2 \mu \mathrm{L}\left(20 \mathrm{ng} \cdot \mu \mathrm{L}^{-1}\right.$ of DNA template) to a $23-\mu \mathrm{L}$ reaction mix containing $11.32 \mu \mathrm{L}$ of milliQ-autoclaved water $+2.5 \mu \mathrm{L}$ of $10 \times$ Taq polymerase buffer (Promega) $+2.3 \mu \mathrm{L} 25$ $\mathrm{mm} \mathrm{MgCl}_{2}+5.7 \mu \mathrm{L}$ deoxynucleotide triphosphates ( $0.5 \mathrm{~mm}$ of each) $+1 \mu \mathrm{L}$ of primer $(5 \mathrm{~mm})$ and $0.18 \mu \mathrm{L}(5$ units $/ \mu \mathrm{L})$ Taq DNA polymerase (Promega). PCR was done with a Perkin Elmer Cetus 9600 thermocycler. Primer selection was based on the ability to generate complex amplification patterns (i.e., three or more amplicons) in a previous set of experiments involving screening of $\approx 200$ primers (unpublished results). The following 10-bp oligonucleotide primers (obtained from Operon Technologies Inc., Alameda, Calif.) were selected and used in the PCR reaction: OPC-9, OPQ-20, and OPV7. PCR reactions were replicated three times (for each combination of primer-tissue-extraction method) to check reproducibility and intrasample variation of the RAPD profiles. The reaction mixture (containing the template DNA) was heated at $94^{\circ} \mathrm{C}$ for 2 min and then subjected to 40 cycles consisting of $30 \mathrm{~s}$ at $94^{\circ} \mathrm{C}, 2 \mathrm{~min}$ at $36^{\circ} \mathrm{C}, 2$ min at $72{ }^{\circ} \mathrm{C}$, and the final step at $72{ }^{\circ} \mathrm{C}$ for $7 \mathrm{~min}$. The reaction products were subjected to electrophoresis on $1.0 \%$ agarose gel in TAE buffer and stained with ethidium bromide (Williams et al., 1990). The amplicon intensity and the average number of detectable amplicons (i.e., total number of scorable bands over total number of methods with at least one scorable band) were used for comparison of relative efficiency between methods, tissues, and purification method-plant tissue combinations.

\section{Results and Discussion}

DNA YIELD. DNA purification method and plant tissue were significant sources of variation $(P=0.01)$ for DNA yield (Table 1$)$. No significant interaction was detected between method and type

Table 2. Amount of genomic DNA ( $\mu \mathrm{g} \cdot \mathrm{g}^{-1}$ of fresh tissue) obtained after purification from six types of carrot tissue (fresh leaves = LF; lyophilized leaves $=\mathrm{LL}$; whole umbellets $=\mathrm{WU}$; calli $=\mathrm{CL}$; whole seeds $=\mathrm{WS}$; and tap roots $=\mathrm{TR})$ using seven methods as described in Materials and Methods . Values are the overall mean of three replications.

\begin{tabular}{|c|c|c|c|c|c|c|c|}
\hline \multirow{2}{*}{$\begin{array}{l}\text { Purification } \\
\text { method }\end{array}$} & \multicolumn{6}{|c|}{ DNA $\left(\mu g \cdot g^{-1}\right.$ fresh tissue $)$} & \multirow{2}{*}{$\begin{array}{c}\text { Method } \\
\text { mean }\end{array}$} \\
\hline & LF & LL & WU & CL & WS & TR & \\
\hline$\overline{1}$ & 70.9 & 65.0 & 182.1 & 24.1 & 69.0 & 7.6 & 69.8 \\
\hline 2 & 33.2 & 23.1 & 114.7 & 18.8 & 54.9 & 5.7 & 41.7 \\
\hline 3 & 37.2 & 34.4 & 107.0 & 18.1 & 54.8 & 5.2 & 42.7 \\
\hline 4 & 32.3 & 25.7 & 76.5 & 23.8 & 45.5 & 2.9 & 34.4 \\
\hline 5 & 58.9 & 50.6 & 131.0 & 29.7 & 60.2 & 2.4 & 55.5 \\
\hline 6 & 56.0 & 46.3 & 108.8 & 21.9 & 53.8 & 2.2 & 48.2 \\
\hline 7 & 45.5 & 31.9 & 88.7 & 17.3 & 42.0 & 4.0 & 38.2 \\
\hline Tissue mean & 47.7 & 39.6 & 115.5 & 22.0 & 54.3 & 4.4 & \\
\hline $\operatorname{LSD}(P<0.01)$ & 27.7 & 24.7 & 61.5 & 12.1 & 17.3 & 3.6 & \\
\hline
\end{tabular}



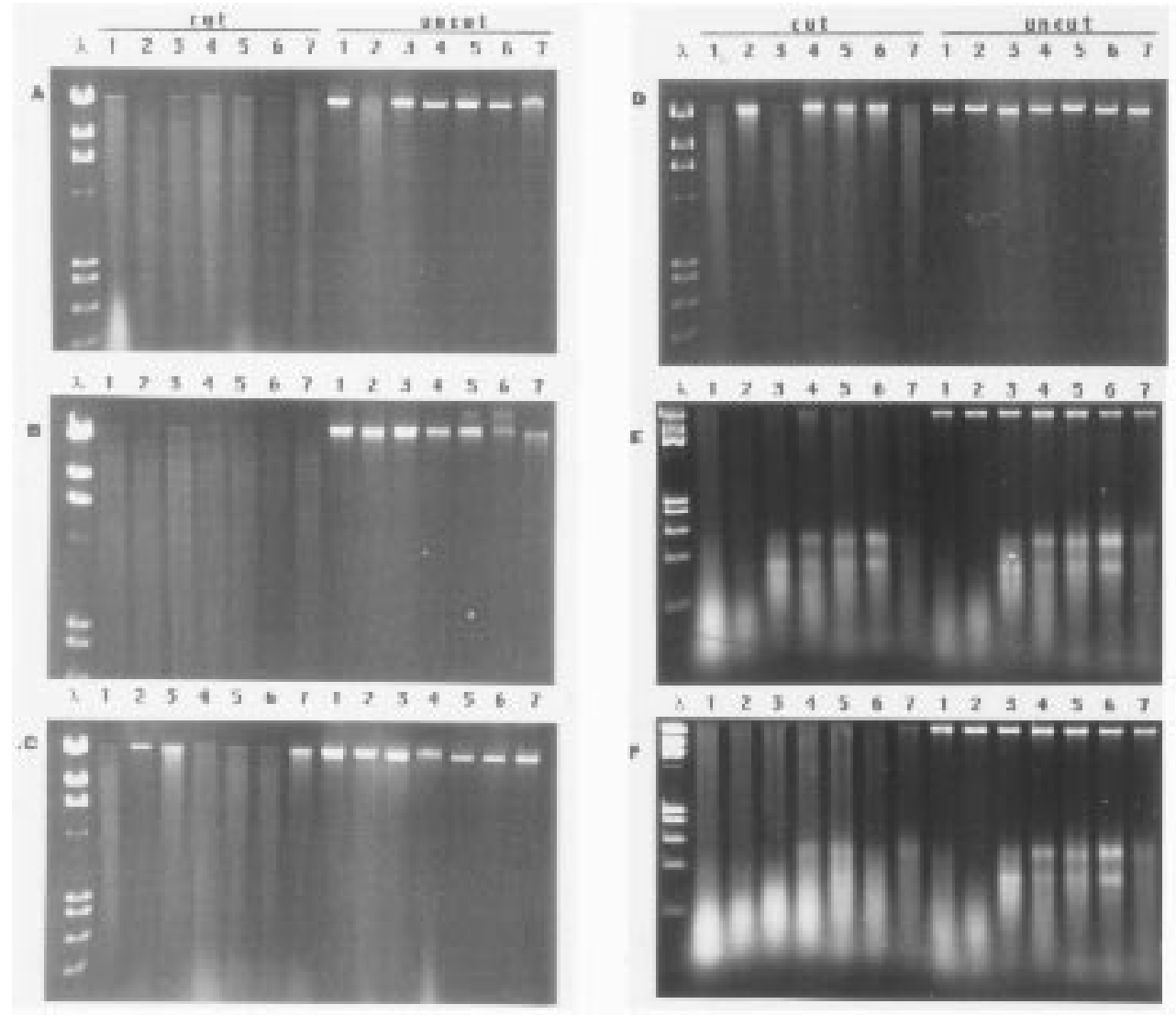

most DNA among the nonorganic methods in five out of six tissues evaluated (Table 2). Plant tissue was the most important source of variation for DNA yield (Table 1). Differences among carrot tissues (Table 2) might be explained by either some intrinsic tissue-specific variation (e.g., number and size of cells; ratio of mitotic to interphase nuclei; and amount of extranuclear DNA) or by singular differences in the structure or biochemical composition of the tissue.

BANDING PATTERN OF THE UNCUT DNA. Banding pattern was not affected by method of extraction or tissue source (Fig. 1 A-F). Degraded or partially degraded DNA preparations were observed only in one replication in methods 2 and 7 in callus tissue, and in one or two replications in methods 6 and 7 in root tissue (Fig. 1).

DNA PURITY. The purity of the extracted DNA varied as determined by the $\mathrm{A}_{260} / \mathrm{A}_{280}$ ratio (Table 3) and was generally of high purity with few exceptions from methods 2, 3, and 7. Whole umbellets and fresh leaves had consistently low values (1.65 or less indicates protein contamination) while lyophilized leaf and callus values usually exceeded

Fig. 1. Agarose $(0.8 \%)$ gel electrophoresis of uncut and HindIII-cleaved (cut) high molecular weight DNA purified from six carrot tissues by seven different procedures as described in Materials and Methods. (A) DNA obtained from calli, (B) tap roots, (C) fresh leaves, (D) whole umbellets, (E) lyophilized leaves, and (F) whole seeds. Lane $\lambda=$ phage lambda DNA cleaved with HindIII, lane $1=$ method 1, lane $2=\operatorname{method} 2$, lane $3=\operatorname{method} 3$, lane $4=\operatorname{method} 4$, lane $5=$ method 5 , lane $6=$ method 6 , lane $7=$ method 7 . Size markers are $23,130 \mathrm{bp}$ (top most), 9416 bp, 6557 bp, 4361 bp (faint band), 2322 bp, 2027 bp, 1568 bp, and 1118 bp, respectively.

of tissue. Inflorescence yielded the most DNA with an overall mean of $115 \mathrm{ng} \cdot \mathrm{mg}^{-1}$ of DNA on a fresh tissue basis followed by whole seeds $\left(54 \mathrm{ng} \cdot \mathrm{mg}^{-1}\right)$, fresh leaves $\left(48 \mathrm{ng} \cdot \mathrm{mg}^{-1}\right)$, lyophilized leaves $\left(40 \mathrm{ng} \cdot \mathrm{mg}^{-1}\right)$, calli $\left(22 \mathrm{ng} \cdot \mathrm{mg}^{-1}\right)$, and tap roots $\left(4 \mathrm{ng} \cdot \mathrm{mg}^{-1}\right)$ (Table 2). Method 1 had a higher overall yield than other methods and was highest in five out of six tissues. Method 5 DNA yields were comparable to method 1 for all tissues but tap root yielded the
1.95, which indicates the presence of RNA (Sambrook et al. 1989). Interestingly, lyophilization apparently reduced protein contamination in virtually all preparations when compared with those obtained from fresh leaves (Table 3 ). The ratio consistently averaged higher than 1.9 for methods $1,4,5$, and 6 . Results within the range observed in the Table 3 were expected because no RNase treatment was performed. RNA contamination can be seen in agarose gels as faster-migrating bands in many samples (Fig. 1).

DNA CLEAVAGE. In fresh leaves, methods $1,4,5$, and 6 presented complete DNA cleavage (Fig. 1C) whereas digestion was incomplete for methods 2 and 7 (Fig. 1C). By contrast, complete cleavage of DNA was observed in all preparations obtained from lyophilized leaves (Fig. 1E). Except for method 7, where slight degradation was observed, DNA integrity was maintained in all methods when using tap roots (Fig. 1B). All DNA preparations were fully digested by HindIII including those originating from

Table 3. Absorbance values (expressed as $\mathrm{A}_{260} / \mathrm{A}_{280}$ ratio) observed in DNA preparations from six carrot tissues (fresh leaves = LF; lyophilized leaves $=\mathrm{LL}$; whole umbellets $=\mathrm{WU}$; calli $=\mathrm{CL}$; whole seeds $=\mathrm{WS}$; and tap roots $=\mathrm{TR}$ ) using seven different methods as described in Materials and Methods. Values represent the overall mean of three replications.

\begin{tabular}{lcccccc}
\hline \hline \multirow{2}{*}{$\begin{array}{l}\text { Purification } \\
\text { method }\end{array}$} & \multicolumn{9}{c}{$\begin{array}{c}\text { Absorbance ratio } \\
\left(\mathrm{A}_{260} / \mathrm{A}_{280} \text { ratio }\right)\end{array}$} \\
\cline { 2 - 6 } & LF & LL & WU & CL & WS & Method \\
\hline 1 & 1.98 & 2.18 & 2.06 & 2.34 & 2.09 & 2.13 \\
3 & 1.42 & 1.99 & 1.31 & 2.11 & 1.42 & 1.44 \\
4 & 1.49 & 1.97 & 1.24 & 2.03 & 2.13 & 1.69 \\
5 & 1.92 & 2.05 & 1.95 & 2.20 & 1.72 & 2.14 \\
6 & 1.92 & 2.27 & 1.98 & 2.26 & 1.65 & 2.08 \\
7 & 1.90 & 2.16 & 1.97 & 2.22 & 1.59 & 2.00 \\
Tissue mean & 1.40 & 2.17 & 1.74 & 1.49 & 1.76 & 1.37 \\
\hline
\end{tabular}


seeds, whole flowers, and fresh leaves by methods 2 and 3, which were highly contaminated by proteins (Fig. 1). In calli, all methods yielded undegraded DNA that was almost fully digestible except for method 2 (Fig. 1A). All methods yielded undegraded DNA preparations when whole umbellets and seeds were used as the tissue source (Fig. 1D and F). In umbellets, complete HindIII digestion was observed only in preparations originated from methods 1, 3, and 7. Partial digestion was observed in methods 2 , 4, 5, and 6 (Fig. 1D). All DNA preparations obtained from tap roots were readily digested by HindIII (Fig. 1B). No qualitative variation was observed for HindIII DNA cleavage among replications.

TisSUE-SPECIFIC COMPOUNDS WITH ADVERSE EFFECTS ON RESTRICTION ENDONUClEASE CLEAVAGE. Our results suggest the copurification of compounds by methods $2,4,5$, and 6 that may adversely affect restriction endonuclease performance (Fig. 1), especially in carrot flowers. Since HindIII is reported to be sensitive to acid polysaccharides (Demeke and Adams, 1992) this group of compounds is the most plausible cause of these inhibitory effects. However, the presence of polyphenolic molecules and proteases in DNA preparations also has been reported to present inhibitory effects on several enzymatic systems, including restriction endonucleases and polymerases (De Boer et al., 1995; Rogers and Bendich, 1994). Complete HindIII cleavage was observed for all tissues only in purified DNA obtained by method 1 (Fig. 1AF) indicating that those putative inhibitory compounds can be eliminated from the final DNA preparation by appropriate choice of DNA extraction method.

TIME REQUIRED FOR DNA PURIFICATION. Marker-assisted selection, cultivar fingerprinting and genome mapping is limited by time and cost associated with the DNA extraction system (Staub et al., 1996; Weising et al., 1995). In our study, the time required for processing samples varied between different methods. The most rapid method was 2 (15 to $20 \mathrm{~min})$, followed by 3 (30 to $40 \mathrm{~min}), 5$ and 7 ( $\approx 1$ h each), 6 (1 to 1.5 h), and, 1 (1 to 2 h). The most time-consuming protocol was method 4 (Dellaporta et al., 1983) which takes on average 3 to $3.5 \mathrm{~h}$ to complete. This protocol also had low DNA yield for flowers and young leaves but this protocol was effective with more problematic tissues (e.g., seeds and roots) as indicated by a reduction in DNA loss (Tables 2 and 3). The ratio obtained with method 4 was comparable to the average of methods 5 and 6 and method 1 that used CTAB + chloroform. A comparison among methods 4,5 , and 6 indicates that several steps can be eliminated for some tissues without compromising either DNA yield or quality (Tables 2 and 3 ).
EFFECT OF THE POLYSACCHARIDE-REMOVING TREATMENT. The incorporation of a polysaccharide-removing high salt protocol (Fang et al., 1992) in methods 3 and 6 had no apparent positive effect on yield and HindIII cleavage. Although method 6 provides slightly higher $A_{260} / A_{280}$ ratios (Table 3 ), it yielded significantly lower amounts of DNA than method 5 (an identical protocol except for the polysaccharide-removing treatment). Moreover, the highsalt wash was not effective in eliminating HindIII inhibitory effects present in the DNA preparations from flowers (Fig. 1D). This procedure was found to be effective in the purification of cucumber and melon DNA (Fang et al., 1992) but in our studies extraction time was increased and the total DNA yield was reduced (Table 1). The benefit associated with high-salt washing, was recorded in the PCR of fresh leaf tissue, where method 6 was the only nonorganic procedure displaying amplicons with all primers (Fig. 2D). However, the high-salt wash alone does not explain this benefit because PCR of DNA purified by method 3 (which also includes identical high-salt wash) did not generate amplicons (Fig. 2D). DNA purified from roots by method 6 did not amplify well using two primers (Fig. 2B).

EFFECT OF THE TISSUE SOURCE AND DNA PURIFICATION METHOD ON RAPD PROFILES. Optimizing PCR parameters for RAPD analysis in plants has been a major research focus (Staub et al., 1996; Weeden et al., 1992; Wolff et al., 1993). Our results demonstrated that

Fig. 2. Agarose (1.0\%) gel showing RAPD PCR amplicons obtained with the primers OPC-9, OPQ-20, and OPV-7 using DNA purified from six carrot tissues by seven different procedures as described in Materials and Methods. (A) Amplicons obtained from calli, $(\mathbf{B})$ tap roots, $(\mathbf{C})$ lyophilized leaves, $(\mathbf{D})$ fresh leaves, $(\mathbf{E})$ whole umbellets, and $(\mathbf{F})$ whole seeds. Lane $\lambda=$ phage lambda DNA cleaved with HindIII, lane $1=$ method 1 , lane $2=$ method 2 , lane $3=$ method 3 , lane $4=\operatorname{method} 4$, lane $5=\operatorname{method} 5$, lane $6=\operatorname{method} 6$, lane $7=\operatorname{method} 7$. Size markers are 23,130 bp (top most), 9416 bp, 6557 bp, 4361 bp (faint band), 2322 bp, 2027 bp, 1568 bp, and 1118 bp, respectively.
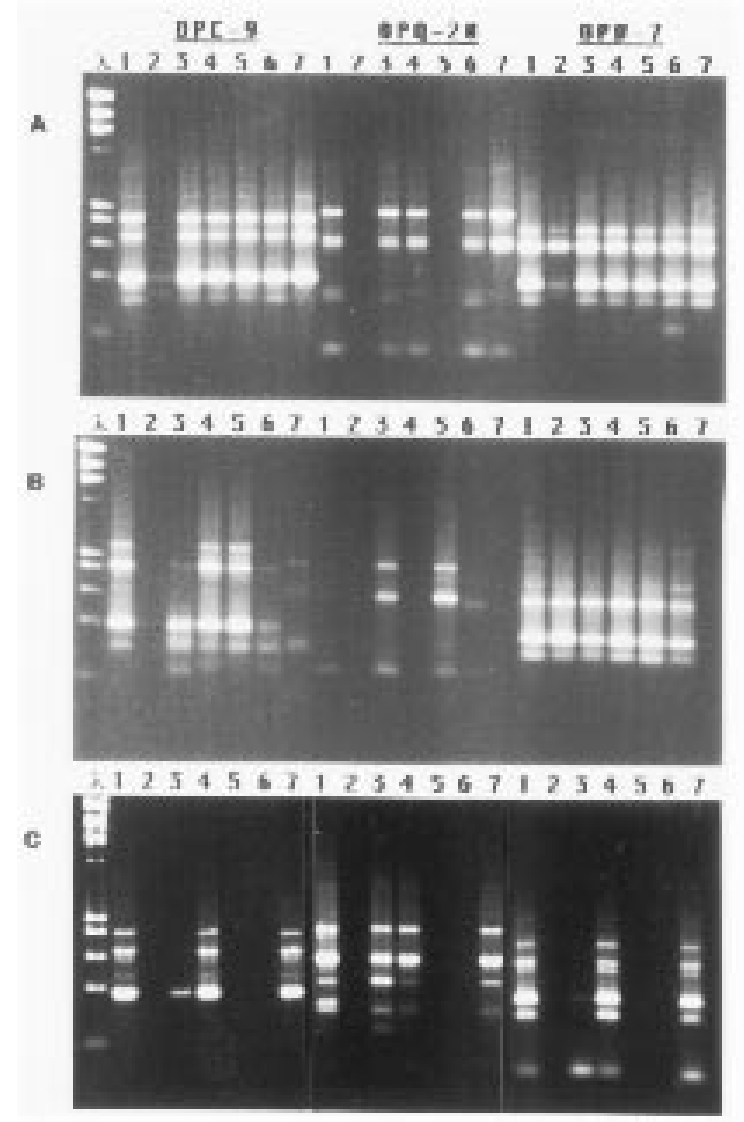

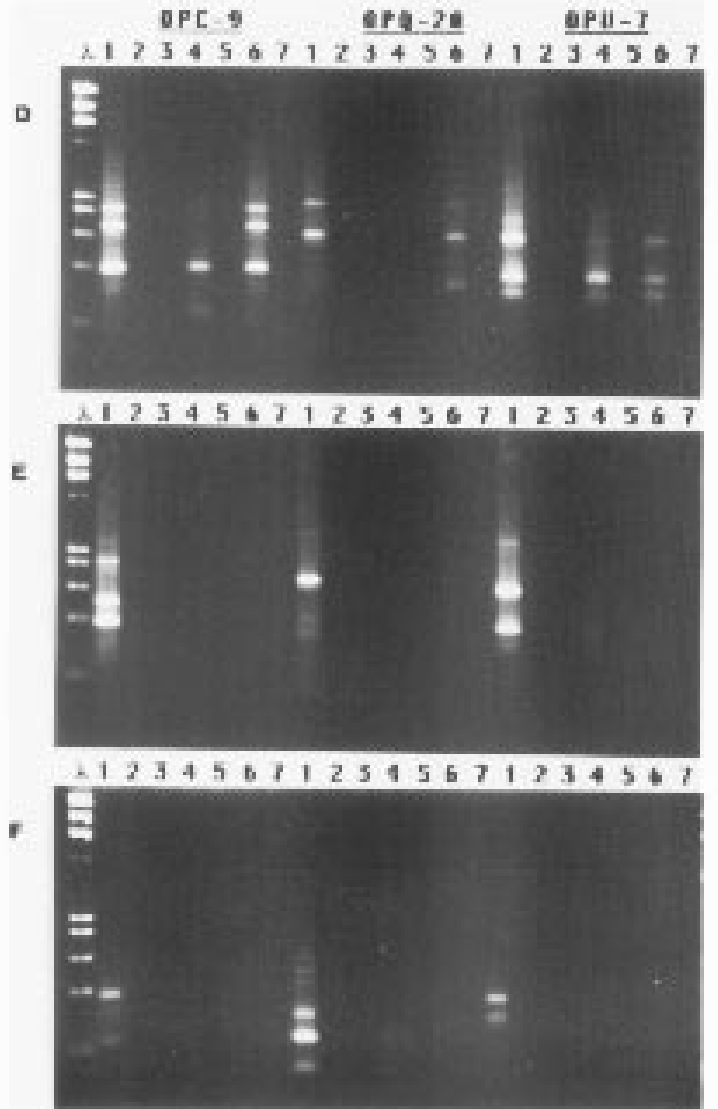



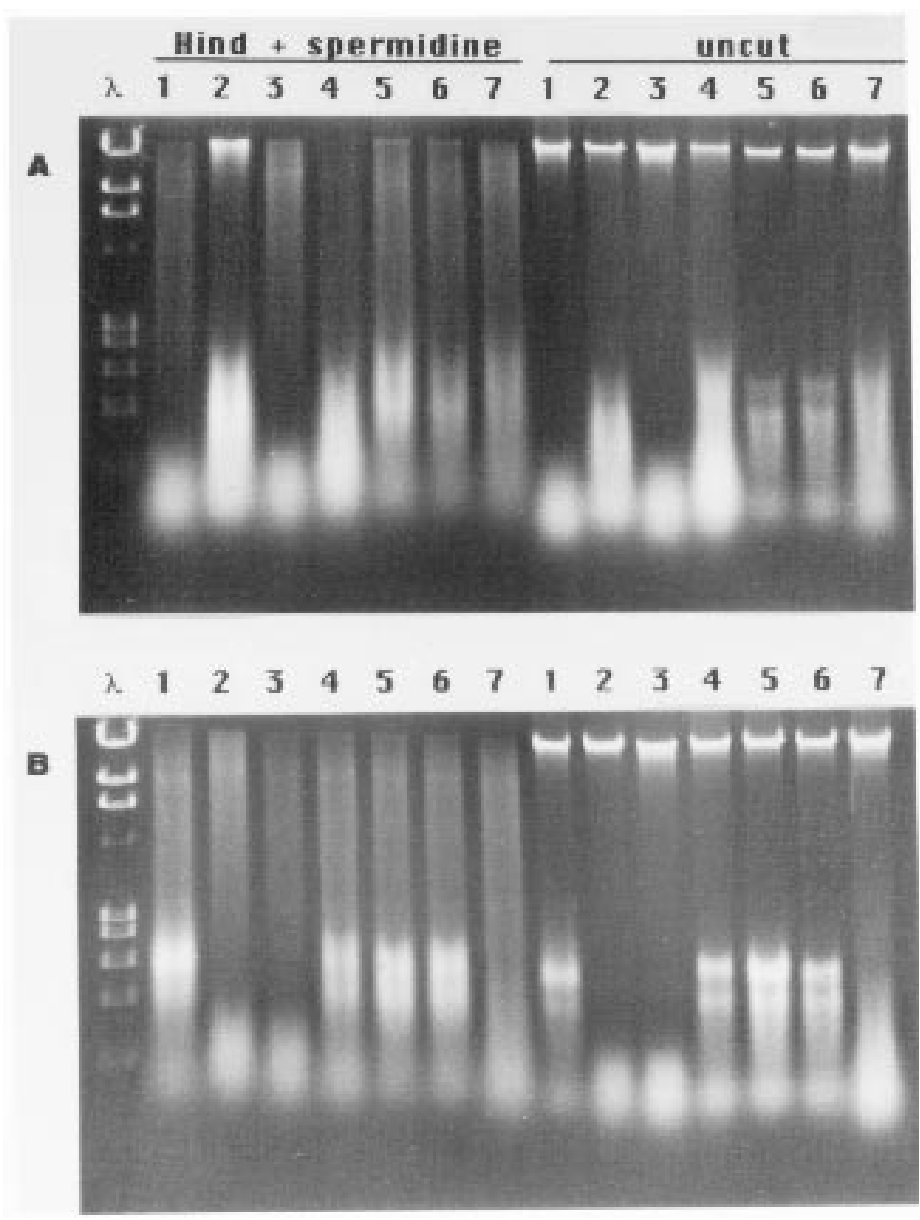

Fig. 3. Agarose (0.8\%) gel of uncut high molecular weight DNA purified from fresh carrot leaves and flowers (whole umbellets) by seven different methods and after treatment with HindIII plus $5 \mu \mathrm{L}$ of spermidine $(0.1 \mathrm{M})$. (A) DNA obtained from fresh leaves. (B) DNA from whole umbellets. Lane $\lambda=$ phage lambda DNA cleaved with HindIII, lane $1=\operatorname{method} 1$, lane $2=\operatorname{method} 2$, lane $3=\operatorname{method} 3$, lane $4=\operatorname{method} 4$, lane $5=\operatorname{method} 5$, lane $6=\operatorname{method} 6$, lane $7=\operatorname{method} 7$. Size markers are 23,130 bp (top most), 9416 bp; 6557 bp, 4361 bp (faint band), 2322 bp, 2027 bp, 1568 bp, and 1118 bp, respectively.

amplification patterns of RAPD fingerprinting can be affected by the plant tissue used. Qualitative and quantitative differences of PCR products were observed (Fig. 2A-F). Callus was the bestDNA source tissue for RAPD analysis. PCR products of callus tissue DNA provided an overall consistently higher number of more intense amplicons than DNA from all other tissues (Fig. 2A-F).

Method 1 yielded DNA that performed best in expressing the amplicons over all tissues (Fig. 2A-F). The average number of detectable bands also varied across the purification method-tissue combinations for all primers (Fig. 2). In contrast to callus and root tissue, (Fig. 2A-B), poor DNA amplification was observed in leaves, seeds and flowers (Fig. 2D-F) in RAPD analysis. In fresh leaves, the average number of amplicons for the primers OPC-9, OPQ-20 and OPV-7 was 2.66, 2.50, and 3.00, respectively. In lyophilized leaves the average number of amplicons produced by the these primers was 4.25, 4.50, and 5.00, respectively (Fig. 2D). In flower and seed tissues, only method 1 allowed for DNA amplification, however, in all cases the number of amplicons was lower than those observed in calli, root or leaves (Fig. 2A-D). This result suggests the copurification by all methods (but to different extracts) of contaminant compounds with direct (or indirect) inhibitory action on Taq polymerase activity in flowers and seeds.
According to our results, method 1 is the only one that can provide a DNA preparation pure enough to allow PCR amplification of some of the amplicons observed in the RAPD profiles of other DNA purification method-tissue combinations (Fig. 2). Overall, only slight variations in the RAPD profiles displayed in Fig. 2 were observed among replications except for two combinations: OPQ20 amplicons were also observed in two replications from DNA obtained by method 5 from callus tissue and in one replication of a root tissue-extraction method 1 combination (results not shown).

An important application of PCR-based markers has been for examining genetic diversity at the DNA level among individuals in a given species or group of closely related species (Weising et al., 1995). RAPD provides one of the most useful systems to estimate the levels of diversity or relatedness available in a germplasm pool (Weising et al., 1995). Skroch and Nienhuis (1995) found scoring error (RAPD amplicon reproducibility) in Phaseolus sp. to be dependent on uniformity of amplification conditions and primer selection according to amplicon strength. We also found differences in primer efficiency and reproducibility. For example, only the primers OPC-9 (one out of five bands) and OPV-7 (three out of six bands) were able to amplify DNA to detectable levels from the completely degraded callus DNA obtained by method 2 (Fig. 2A). Slight but detectable amplification bands were observed with the primers OPC-9 (two out of five) and OPQ-20 (one out of five) even when using the partially degraded DNA from root tissue extracted with method 7 (Fig. 2B).

Furthermore, according to our results, the tissue source for DNA extraction should be also taken into account. An identical amplicon profile was observed after PCR amplification in almost all combinations of purification method-primer using intact DNA samples originating from callus (Fig. 2A). However, differences in band number and intensity were observed in other combinations of primers-extraction methods-tissues (Fig. 2). By comparing RAPD results of DNA extracted from the same inbred line (Fig. 2B-F), fresh leaves and root tissue generated the highest number of nonexpected polymorphic bands, which originated probably by differences in the extraction method and tissue source. Some methods, even though yielding intact DNA, could not be amplified (e.g., method 2 in root tissue for the primers OPC-9 and OPQ-20; Fig. 3B, lane 2). Overall, three to five major RAPD bands were amplified by all primer-extraction method-tissue combinations but the number of unambiguous amplicons (i.e., present in all combinations) was less than two (Fig. 2A-F).

Amplicons deviating from genetic expectations (pseudo-polymorphic) observed in carrot were generated by false negatives (i.e., absence of a genetically expected amplification product) as inferred by control PCR reactions carried out in identical conditions but without the template DNA (data not shown). False negatives in PCR have been explained by the sensitivity of the Taq DNA polymerase to reagents commonly used in DNA extraction buffer rather than by components of the biological material (Gelfand and White, 1990; Staub et al., 1996) but tissue-specific differences in DNA purity and pseudopolymorphisms we observed suggest a role for naturally occurring contaminants as another source of false negatives (Fig. 2A-F). In accordance with previous reports (e.g., Weeden et al., 1992; Staub et al., 1996), our results showed that integrity of the final DNA preparation is a major factor in genetic analysis using RAPDs. DNA from degraded or partially degraded preparations generated none and/or lower number of detectable bands after PCR reaction (compare Figs. 1 and 2).

IDENTIFICATION OF THE BEST COMBINATIONS OF TISSUE AND DNA PURIFICATION PROTOCOLS. Each of the methods and combinations of extraction method and tissue studied here may be useful for 
distinct purposes. If DNA is to be used directly in DNA-DNA hybridization, methods 1 and 5 are recommended because they provide DNA preparations with high yield and suitability for restriction enzyme digestion. These recommendations can be extended to RFLP-based molecular mapping where DNA yield and appropriate DNA cleavage are crucial considerations. In addition, inflorescence (for method 1) and fresh or lyophilized leaves (for methods 1 and 5) can be recommended as source of DNA for use in Southern transfer and RFLP analysis in carrot.

If the DNA is to be used in PCR-based systems, then DNA purity is critical. In this case, lyophilized leaves and calli are the tissues of choice when the DNA is extracted by methods $1,4,5,6$, and 7. Method 2 was the simplest method but final preparations had considerable protein contamination (Table 3 ) and degraded DNA was observed in some replications (Fig. 1). Method 2 was inadequate for RAPD analysis in carrot regardless of tissues used or DNA purification methods (Fig. 2A-F). Method 3 (a modification of method 2) was the nonorganic method that preserved both DNA integrity and HindIII cleavage in all tissues evaluated without spermidine treatment (Fig. 1). This protocol, however, yielded relatively low DNA concentrations in some carrot tissues (Table 2). DNA from method 3 was inadequate for RAPD analysis when using DNA from flowers and fresh leaves (Fig. 2). False negatives in root and lyophilized leaf tissue were also observed with method 3 DNA (Fig. 2).

Our studies indicate that none of the nonorganic methods tested gave clear advantages over the chloroform to isoamylalcohol ratio of precipitation (method 1) in relation to DNA yield, quality, and utility. In addition, the nonorganic methods with the best performance (methods 4, 5, and 6) presented DNA preparations in which restriction endonuclease digestion was adversely affected as has been previously noted (Dellaporta et al., 1983). This problem was overcome by adding $5 \mu \mathrm{L}$ of $0.1 \mathrm{~m}$ spermidine to the final DNA preparation before restriction enzyme digestion. We have tested this approach with complete DNA digestion observed in problematic samples of carrot DNA from methods 4,5 , and 6 but not 2 (Fig. 3).

IMPLICATION ON CARROT BREEDING AND GENETICS. Our results indicate that the final concentration, quality, and restriction endonuclase cleavage of DNA preparations is very sensitive to the tissue source and DNA purification method in carrot. This observation has a series of practical implications for breeding and genetics of this vegetable crop. Correct interpretation of true genetic differences between individuals in segregating populations and comparative genetic analysis such as genetic fingerprinting may be adversely affected, for example, by low quality DNA obtained from certain tissue-extraction method combinations. In our work, it was clear that some carrot RAPD markers, obtained under certain experimental conditions, did not present satisfactory levels of reproducibility. Therefore, judicious and uniform selection of DNA purification method and tissue source will be required for reliable RAPD-based DNA fingerprinting analysis in carrot.

\section{Literature Cited}

Arnheim, N. and H. Erlich. 1992. Polymerase chain reaction strategy. Annu. Rev. Biochem. 61:131-156.

Chaves, A.L., C.E. Vergara, and J.E. Mayer. 1995. Dichloromethane as an economic alternative to chloroform in the extraction of DNA from plant tissues. Plant Mol. Biol. Rptr. 13:18-25.

De Boer, S.H., L.J. Ward, X. Li, and S. Chittaranjan. 1995. Attenuation of PCR inhibition in the presence of plant compounds by addition of BLOTTO. Nucleic Acids Res. 23:2567-2568.

Dellaporta, S.L., J. Wood, and J.B. Hicks. 1983. A plant DNA minipreparation:
Version II. Plant Mol. Biol. Rptr. 1:19-21

Demeke, T. and R.P. Adams. 1992. The effects of plant polysaccharides and buffer additives on PCR. Biotechniques 12:332-334.

Do, N. and R.P. Adams. 1991. A simple technique for removing polysaccharide contaminants from DNA. Biotechniques 10:162-166.

Doyle, J.J. and J.L. Doyle. 1990. Isolation of plant DNA from fresh tissue. Focus 12:13-15.

Edwards, K., C. Johnstone, and C. Thompson. 1991. A simple and rapid method for the preparation of plant genomic DNA for PCR analysis. Nucleic Acids Res. 19:1349.

Fang, G., S.Hammer, and R. Grumet. 1992. A quick and inexpensive method for removing polysaccharides from plant genomic DNA. BioTechniques 13:52-55.

Furokawa, K. and V.P. Bhavadna. 1983. Influences of amniotic polysaccharides on DNA synthesis in isolated nuclei and by DNA polymerase: Correlation of observed effects with properties of the polysaccharides. Biochem. Biophys. Acta 740:466-475.

Gelfand, D.H and T.J. White. 1990. Thermostable DNA polymerases, p. 129-141. In: M.A. Innis, D.H. Gelfand, J.J. Sninsky and T.J. White (eds.). PCR protocols. A guide to methods and applications. Academic Press, San Diego.

Hattori, J., S.G. Gottlob-McHugh, and D.A. Johnson. 1987. The isolation of highmolecular-weight DNA from plants. Anal. Biochem. 165:70-74.

Koebner R.M.D. 1995. Predigestion of DNA template improves the level of polymorphism of random amplified polymorphic DNA in wheat. Genet. Anal. Biomol. Eng. 12:63-67

Murashige, T. and F. Skoog. 1962. A revised medium for rapid growth and bio assays with tobacco tissue cultures. Physiol. Plant. 15:473-497.

Murray, M.G. and W.F. Thompson. 1980. Rapid isolation of high molecular weight plant DNA. Nucleic Acids Res. 8:4321-4325.

Riede C.R., D.J. Fairbanks, W.R. Andersen, R.L. Kehrer and L.R. Robinson. 1994. Enhancement of RAPD analysis by restriction-endonuclease digestion of template DNA in wheat. Plant Breeding 113:254-257.

Rogers, S.O. and A.J. Bendich. 1994. Extraction of total cellular DNA from plants, algae and fungi. In: S.B. Gelvin and R.A. Schilperoort (eds.). Plant molecular biology manual. 2nd ed. Kluwer Academic Publishers, Dordrecht.

Saghai-Maroof, M.A., K.M. Soliman, R.A. Jorgensen, and R.W. Allard. 1984. Ribosomal DNA spacer-length polymorphisms in barley: Mendelian inheritance, chromosomal location, and population dynamics. Proc. Natl. Acad. Sci. USA 81:8014-8018.

Sambrook, J., E.F. Fritsch, and T. Maniatis. 1989. Molecular cloning: A laboratory manual. 2nd ed. Cold Springer Harbor Laboratory, Cold Spring Harbor, N.Y.

Schulz, B., L. Westphal, and G. Wricke. 1994. Linkage groups of isozymes, RFLP and RAPD markers in carrot (Daucus carota L. sativus). Euphytica 74:67-76.

Shioda, M. and K. Marakami-Muofushi. 1987. Selective inhibition of DNA polymerase by a polysaccharide purified from slime of Physarum polycephalum. Biochem. Biophys. Res. Commun. 146:61-66.

Simon. P.W., C.E. Peterson, and W.H. Gabelman. 1990. B493 and B9304, carrot inbreds for use in breeding, genetics, and tissue culture. HortScience 25:815.

Skroch P.W. and J. Nienhuis. 1995. Impact on scoring error and reproducibility of RAPD data on RAPD based estimates of genetic distance. Theor. Appl. Genet. 91:1086-1091.

Steenkamp, J., I. Wiid, A. Lourens, and P. Van Helden. 1994. Improved method for DNA extraction from Vitis vinifera. Amer. J. Viticult. Enol. 45:102-106.

Staub, J., J. Bacher, and K. Poeter. 1996. Sources of potential errors in the application of random amplified polymorphic DNAs in cucumber. HortScience 31:262-266

Vivek, B.S. and P.W. Simon. 1998. Genetic relationships and diversity in carrot and other Daucus taxa based on nuclear restriction fragment length polymorphisms (nRFLPs). J. Amer. Soc. Hort. Sci. 123:(6):1053-1057.

Wang, H., M. Qi, and A.J. Cutler. 1993. A simple method of preparing plant samples for PCR. Nucleic Acids Res. 21:4153-4154.

Weeden, N.F., M. Timmerman, M. Hermmat, B.E. Kneen, and M.A. Lodhi. 1992. Inheritance and reliability of RAPD markers, p. 12-17. Proc. Symp. Applications of RAPD Technology to Plant Breeding. Minneapolis, Minn.

Weising, K., H. Nybom, K. Wolff, and W. Meyer. 1995. DNA fingerprinting in plants and fungi. CRC Press, Boca Raton, Fla.

Williams, J.G.K., A.R. Kubelik, J.A. Livak, J.A. Rafalski, and S.V. Tingey. 1990 DNA polymorphisms amplified by arbitrary primers are useful as genetic markers. Nucleic Acids Res. 18:6531-6535.

Wolff K., E.D. Schoen, and J. Peters-van Rijn. 1993. Optimizing the generation of random amplified polymorphic DNAs in chrysanthemum. Theor. Appl. Genet. 86:1033-1037. 